\title{
Magazine of
}
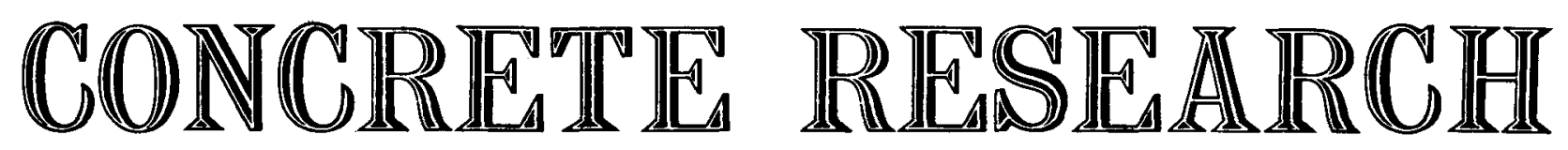

Volume 12, Number 36: November 1960

EDITORIAL ADVISORY BOARD

A. L. L. Baker, D.Sc.(Eng.), M.I.C.E., M.I.Struct.E.

Professor of Concrete Technology, University of London, Imperial College of Science and Technology

W. Fisher Cassie, Ph.D., M.S., F.R.S.E., M.I.C.E., M.I.Struct.E.

Professor of Civil Engineering, University of Durham, King's College, Newcastle upon Tyne

R. H. Evans, C.B.E., D.Sc., D.ès Sc., Ph.D., M.I.C.E., M.I.Mech.E., M.I.Struct.E.

Professor of Civil Engineering, University of Leeds

T. W. Parker, M.Sc., Ph.D., F.R.I.C.

Deputy Director of Building Research, Department of Scientific and Industrial Research

A. D. Ross, B.Sc., Ph.D., F.R.S.E., M.I.C.E.

Professor of Civil Engineering, University of London, King's College

SECRETARY TO THE BOARD AND EDITOR

Ralph P. Andrew, M.A., Ph.D.

Published by the Cement and Concrete Association, 52 Grosvenor Gardens, London, SWl : Belgravia 6661 


\section{Editorial comment}

THE DISTRIBUTION OF STRESSES in the neighbourhood of concentrated loads is a subject which has attracted the attention of engineers and mathematicians for many years, and which still continues to pose problems in the design of certain structural elements. Although the principle enunciated by St. Venant enables the designer to ignore the means by which the load is applied when considering zones outside its immediate vicinity, nevertheless he must ensure that the application of such a load will not cause local failure of the structure.

Very heavy loads concentrated over a small area do not usually occur in a structure. An important exception arises in the case of prestressed concrete, however, particularly in the case of members prestressed by post-tensioning. In a post-tensioned beam the force exerted by a single tendon may well be 50 tons, and this force has to be transmitted to the concrete. In a large beam of, say, $10 \mathrm{ft}^{2}$ cross-sectional area, there may well be 15 such tendons, the force from each of which must be transferred to the end of the concrete beam.

The design of the ends of such prestressed concrete beams-the anchorage zones - is at present largely empirical, although several research workers have attempted theoretical analyses and some experimental work has been done. Indeed, in Magazine of Concrete Research No. 34, Douglas and Trahair presented some theoretical and experimental data on the distribution of stress in anchorage zones.

In view of the need for further information on this problem, the Structures Department of the C \& C A Research Station have been carrying out an extensive investigation into the stress distribution in anchorage zones; the first stage of this work has now been completed, and the results are published in Research Report No. $9^{*}$ by Zielinski and Rowe. The specific aspect of the problem considered in this report is the distribution of stress on the surface of square concrete prisms subjected to concentrated loads applied in the way that is used in the various post-tensioning systems employed in the United Kingdom. The test results differ considerably from the theoretical deductions of Guyon and Magnel, which are widely used in the design of end-blocks, and a new empirical design method is suggested, based on the test results.

Obviously this is not the end of the story. The work described by Zieliński and Rowe only covers square end-blocks subjected to a single load. The research is continuing, however; the internal stress distribution

\footnotetext{
*ZIELIŃSKI, J. and ROWE, R. E. An investigation of the stress distribution in the anchorage zones of post-tensioned concrete members. London, Cement and Concrete Association, Sept-
} ember 1960. pp. 32. Research Report No. 9. is being investigated, and the work extended to cover the interaction of groups of concentrated loads on end-blocks of various sections. Meanwhile it is hoped that publication of the results obtained so far will be of considerable use to practising engineers concerned with the design of post-tensioned concrete units.

A number of important congresses concerned with concrete construction are to be held in 1961, and for the benefit of those interested a list is given below. These congresses provide a valuable opportunity for engincers to learn what their colleagues in other countries are thinking and doing, not only through the formal papers presented but also-and often more effectively - through the valuable informal discussions which take place outside the congress hall. The contacts made at such meetings have an incalculable value in co-ordinating research in different parts of the world, leading as they do to the exchange through personal correspondence of information which has not yet reached the stage where publication would be appropriate. Such informal co-ordination probably has much more direct effect on current research than has the organized co-ordination attempted by the various international committees which exist for this purpose.

\section{5-7 January 1961}

F.I.P.-R.I.L.E.M. Symposium: "Grout for prestressed concrete" at Trondheim, Norway. Applications should be made to Prof. Dr Techn Inge Lyse, Norges Tekniske Hogskole, Trondheim, Norway.

\section{4-18 March 196.1}

I.A.S.S. Colloquium: "Precast shell structures" at Dresden, East Germany. Applications should be made to Dr Ing. H. Rühle, Dostojewskistrasse 10, Dresden-Loschwitz, Germany D.D.R.

\section{1-3 August 1961}

R.I.L.E.M. Symposium: " Durability of concrete " at Prague, Czechoslovakia. Applications should be made to Prof. Ing. Dr B. Hacar, Šolínova 7, Dejvice, Praha 6, Czechoslovakia.

\section{August-2 September 1961}

I.A.S.S. Colloquium: "Experimental research on shell structures" at Delft, Holland. Applications should be made to Prof. Ir A. L. Bouma, Technische Hogeschool te Delft, Postbus 5, Delft, Netherlands.

\section{4-6 September 1961}

I.A.S.S. Colloquium: "Simplified methods of calculation for shells" at Brussels, Belgium. Applications should be made to Prof. P. Dutron, $126 \mathrm{Av}$. Adolphe Buyl, Bruxelles 5, Belgium. 